\title{
Degree of Student's Assimilation to the Meaning of the Term Citizenships in the Schools High Grade Basic Level in Jordan
}

\author{
Mohamed Saleem Al-Zboon ${ }^{1}$ \\ ${ }^{1}$ Department of Foundations of Educations, Zarqa University, Jordan \\ Correspondence: Mohamed Saleem Al-Zboon, Department of Foundations of Educations, Zarqa University, \\ Jordan. E-mail: m.alzboon@ju.edu.jo
}

Received: December 9, 2013 Accepted: January 11, 2014 Online Published: January 26, 2014

doi:10.5539/ies.v7n2p137

URL: http://dx.doi.org/10.5539/ies.v7n2p137

\begin{abstract}
This study aimed at identifying the degree of the Assimilation of the meaning of the term "CITIZENSHIP" by the high grade basic level school students in Jordan. The research sample was composed of (1116) male and female students during the scholastic year 2012/2013. To collect data and then measure results, the standard measurement tool for the meaning of citizenship was made up of (36) questions distributed over (12) "understandings" of the term citizenship, whereby each understanding was allocated three "positions" of the multiple choices given. The results of the research showed that the degree of students' understanding of the concept of citizenship reached a positive percentage of (81\%). Results also showed the presence of statistically high significant differences attributable to gender-variant towards female students in the majority of concepts; the study also showed significant statistical differences attributable to the place of residence, showing more positive understanding of students living in rural areas.

In the light of the results of this study, the researcher presented a set of recommendations which will hopefully help policy makers and educational curricula in Jordanian schools to promote the positive direction of students on the concept of good citizenship.
\end{abstract}

Keywords: assimilation, school basic high-level, good citizenship

\section{Introduction}

The human nature is united and integrated, and the effect of one aspect cannot be isolated from the other aspects of this nature; thereby education has its important role in the development of the human personality in all aspects.

Herbert Spencer says: "If education is the preparation tool for public life, then civic education is to educate and create a good citizen", and he adds that "homeland is defined by its laws, traditions, customs, habits and the relationship networks in it, and that's what is called civic education", thereby civic education is patriotism, and the sense of belonging to the homeland with a historical heritage, customs, and traditions, beside its responsibilities with the community (Nasser, 2003).

Civic Education is an important component of education that cultivates citizens to participate in public life and democracy, to use their rights and to discharge their responsibilities with the necessary knowledge and skills. Jordanian schools should have an advanced distinctively civic mission since the earliest days of the kingdom, it was immediately recognized that a free society must ultimately depend on its citizens, and that the way to infuse people with the necessary qualities is ultimately through education too (Nasser, 2004).

Civic education gives the citizen the concepts, attitudes, values and skills of good citizenship such as respecting rules of the Constitution and obeying law, beside the awareness of his rights, commitments, duties, and belonging and loyalty, in which forming a sense of responsibility, and equity, justice acceptance of others and political participation.

Education addresses the human mind, citizen and student, to provide them with the necessary knowledge about the history of their country and with the necessary information about their rights and duties which are based on the promotion of humanitarian principles and values, and the cultural contemporary embedded in curriculum.

Citizenship is one of the enormous challenges facing modern state, and its citizens, either building an active 
citizen aware of his responsibilities and rights, or drowning in various forms of dispersion, corruption, and narrow loyalties. Modern state is not just the institutions, government and the written Constitution, and it's not the army and the law, but it's the community based integrated projects of cooperation with the close interaction between citizens, as they are the only source of power.

Based on this, some educators go with the need of teaching national education in the early elementary school, where students start forming emotional trends about various systems. National education as a political and social upbringing tool; is a process that helps understanding the reasons for which individuals in the community differ in their social and political behavior, though most of them are in the same society and subjected to the same social and political cultural environment, but as they are not exposed to same manners with the same force, and of course they do not learn the same things (Nasser, 2004).

the importance of the concepts and its active role in the development of cognitive structure had a lot of educators and practitioners in the field of education focusing on the conceptual, where Piaget sees that, cognitive development is an a cumulative process, and the concepts that the child incorporate will build his knowledge in the earlier stage as it is the formal operational stage. Although the stage of the application of the concepts represented in life situations experienced by an individual can be done at a later stage, after he gains the so-called process of balance, which is considered by Piaget as a key factor in shaping the experiences of the individual, in addition, this balancing process acts as a coordinator with the rest of the factors according to Piaget's theory, and accompanies with two types of processes: the process of assimilation and adaptation, so as to work in a synchronized manner to achieve the adjustment between the individual and the environment (Hassan, 2002).

Concepts learning are an objective that education focus on, in various educational levels, therefore, education is the way to save the nation, and it must emanate from the characteristics of the times in which they live, and the characteristics of the national aspects; to influence and contribute in the development of national characteristics.

\section{Problem of the Study}

In light of the security and economic challenges facing Jordan at various levels, came this study to measure and assess the student's degree of assimilation to the meaning of the term citizenships at the higher basic stage in the schools in Jordan, so the problem of the study is to answer the central question: what is the degree of assimilation of the higher basic stage school students to the meaning of the term citizenships in Jordan?

\section{Importance of the Study}

Importance of the study can be summarized by the expected goals learned from the results of this study, so that it becomes an aid to educators and officials responsible for the affairs of the curriculum and education by providing them with the appropriate knowledge for creating a good citizen; belonging to his homeland and committed to the principles of good citizenship.

\section{Objectives of the Study}

The study aimed at achieving the following objectives:

Identify student's degree of assimilation to the meaning of the term citizenships at the higher basic stage in the schools in Jordan.

Identify the student's differences in the degree of assimilation to the meaning of the term citizenships at the higher basic stage in the schools in Jordan, upon gender, residence, and education level of the parents.

\section{Questions of the Study}

The study attempts to answer the following questions:

(1) What is the student's degree of assimilation to the meaning of the term citizenships at the higher basic stage in the schools in Jordan?

(2) Does the student's degree of assimilation to the meaning of the term citizenships at the higher basic stage in the schools in Jordan vary according to gender?

(3) Does the student's degree of assimilation to the meaning of the term citizenships at the higher basic stage in the schools in Jordan vary according to place of residence?

\section{Terms of the Study}

\subsection{Assimilation}

The process of absorbing, representing and digesting the internal and external cultural elements, and 
procedurally it means accommodating, classifying and distributing the new complementary experiences of intellectual constructs, and these processes can be integrated in a unified cultural model, as Bin Tarif and Al-Zboon (2009) study had adopted this procedural definition.

\subsection{Citizenship}

In terminology it is belongingness to the soil of the homeland, which is determined by the geographic limits, and that who belongs to this soil becomes a citizen with rights and responsibilities as dictated by the necessities of commitment to the process of such citizenship (Nasser, 2003).

And procedurally it is an emotional and behavioral expression in which students can reflect their love and loyalty to their country and their nation, based on their perception as they are part of this country, and they have rights and duties towards the society, and it is measured by the student's answers in the study tool for this purpose.

\subsection{Representation of Good Citizenship Values}

It is what achieved by the student's degree of assimilation to the meaning of the term citizenships at the higher basic stage in the schools in Jordan, in light of their response to the scale values of good citizenship prepared for the purposes of this study, as responses could be positive, neutral or negative.

\subsection{Concept}

It is the sum of all characteristics describing the meaning of a subject, as its language meaning reflects the mental readiness to develop and visualize good things.

And procedurally, concept in this study is defined as a set of terms that have a relationship to citizenship, and are intended for the purposes of the present study (belongingness, loyalty, rights, duties, justice, cooperation, solidarity, equity, responsibility, participation, and pride).

\section{Previous Studies}

Many studies have been conducted on the concept of national education and citizenship, and the representing of the students in schools or universities for these concepts, both nationally and socially.

England's (2000) study entitled "Rethinking democracy and education: towards an education of deliberative citizens", in which the researcher is trying to understand the new vision of the relationship between democracy and education, grounded on deliberative democracy, showing that the educational process and the democratic concept of education is based on rationality and effective communication.

Tarabiya (2002) conducted a study entitled: "political concepts contained in the high school curriculum in Jordan, and the extent of awareness of students in the first academic year of these concepts", which aimed at determining the political concepts contained in the high school curriculum in Jordan, and the extent of awareness of students in the first academic year of these concepts, the study detected whether the awareness of these political concepts are represented among students according to gender, location of the university and specialization, the researcher prepared two questionnaires, and were distributed to the members of the study sample, consisting of (710) students, and the results showed that the average relative importance of the political concepts contained in the high school curriculum in Jordan, and the extent of awareness of students in the first academic year of these concepts has reached $(86.74 \%)$, and the study results showed that there are no statistically significant differences at the level of significance $(\alpha \leq 0.005)$ attributable to the geographic location of the university, and or no statistically significant differences at the level of significance $(\alpha \leq 0.005)$ attributable to gender (Jarrar \& Althubetat, 2013).

Then came Kerr (2003) study entitled "Citizenship among students of (14) years age", which aimed at identifying the students orientations for citizenship in Britain, where the sample consisted of a randomly selected students with the age group of (14-28 years), the study pointed the fact that teaching civic education (citizenship) is a complex process that carries out many opportunities and many dimensions inside and outside the school, and the study also showed that many students know the basics of democracy, but they still lacking the deep knowledge of its practices, and that these understanding that democracy is just the practice of voting in elections, the study concluded that, students with higher awareness are more civil ability to participate in political activities and acts like an adult volunteer.

Al-Subaihi (2005) also conducted a study entitled: "Citizenship as perceived by high school students in Saudi Arabia", aiming at identifying the trends in secondary school students toward citizenship and knowledge, in certain social institutions (mosques, schools, families), the study sample consisted of 140 students from the third level in the high schools of Jordan, and the study showed that the trends of secondary school students about citizenship came high, and that the mosque and the school and the family played a major role in the education of 
citizenship and the development of the values of loyalty and belongingness, justice, equity, rights and obligations, and $(80 \%)$ of the students are aware of the rights and obligations of citizenship, and that the percentage of students who have demonstrated satisfaction for their performance in the duties were $(89.9 \%)$ and the percentage of students who have demonstrated satisfaction for achievement of their rights are (55.3\%).

Another study was conducted by Al-Qahtani (2010) entitled "Young people citizenship values and their contribution in strengthening the preventive security", aiming at determining the representing level of these values of citizenship among young people in the universities in of Saudi Arabia, and the degree of their contribution in strengthening preventive security, study was conducted on a random sample of male students in King Abdul Aziz, King Fahd, King Khalid, Tabuk, Imam Muhammad bin Saud and Petroleum and Minerals Universities aged 18-23 years, during the academic year 2009-2010, the sample consisted of 384 students, the study found that there is a rise in the value of participation and that the majority of respondents agreed that the value of this participation contributes in strengthening preventive security.

In conclusion, there are many foreign and Arab studies that discussing this issue, the researcher have benefited from these studies in the development of the objectives, questions, procedures and methods of the current study.

\section{Methods and Procedures}

\subsection{Study Population}

The study population consisted of all students in the higher primary stage in Zarqa Governorate, with a total number of 13950 student from three classrooms, eighth, ninth and tenth, distributed on three educational directorates in Zarqa Governorate.

\subsection{The Study Sample}

The study sample consisted of 1116 male and female students from the higher basic stage, forming $8 \%$ of the study population, and has been chosen randomly, taking into account the classification of schools by the Jordanian educational directorates, and its geographical location and the gender of the students, and Table 1 shows the distribution of the study sample according to the study variables: gender and place of residence.

Table 1 . The frequencies and percentages of the study sample according to the study variables: gender and place of residence

\begin{tabular}{ccccc}
\hline & Variable & & Frequency & Percentage \\
\hline \multirow{2}{*}{ Gender } & & Male & 592 & $53.05 \%$ \\
& & Female & 524 & $46.95 \%$ \\
\hline \multirow{2}{*}{ Residence } & & City & 745 & $66.76 \%$ \\
& & Village & 371 & $33.24 \%$ \\
\hline & Total & & 1116 & $100 \%$ \\
\hline
\end{tabular}

\subsection{The Limits of the Study}

This study is limited to students of the higher basic stage in the public schools of Zarka Governorate in Jordan for the academic year 2012/2013, and is determined by the results of the student's degree of assimilation to the meaning of the term citizenships at the higher basic stage in the schools in Jordan, as determined by the results of the designed study tool and statistical procedures used.

\subsection{Study Variables}

The study included dependent variable which represents the student's degree of assimilation to the meaning of the term citizenships at the higher basic stage in the schools in Jordan. And two independent variables: gender and residence (City or Village).

\subsection{The Study Tool}

the study tool consisted of two parts: the first one contains general information of the transponder, namely: gender, place of residence, while the second is a questionnaire to measure the student's degree of assimilation to the meaning of the term citizenships at the higher basic stage in the schools in Jordan as perceived and applied by students, which is developed by the researcher based on several Arab and foreign previous studies, and the theoretical literature in this area, and it consisted of (36) situations with multiple choice of three alternatives, so 
that the student can choose the alternative most suitable and appropriate to him, therefore, the assimilation of the concept of the positive choice is given (3) degrees and the assimilation of the concept of the neutral choice is given (2) degree, and the negative choice is given (1) degree.

The number of concepts included in the study were 12, each with three alternatives to measure the degree of assimilation of the higher basic stage school students to the meaning of the term good citizenships in Jordan, where attitudes $(1,2,3)$ represent the concept of belongingness, and attitudes $(4,5,6)$ represent the concept of loyalty, and attitudes $(7,8,9)$ represent the concept of rights, and attitudes $(10,11,12)$ represent the concept of duties, and attitudes $(13,14,15)$ represent the concept of justice, and attitudes $(16,17,18)$ represent the concept of cooperation, and attitudes $(19,20,21)$ represent the concept of solidarity, and attitudes $(22,23,24)$ represent the concept of equity, and attitudes $(25,26,27)$ represent the concept of responsibility, and attitudes $(28,29,30)$ represent the concept of participation, and attitudes $(31,32,33)$ represent the concept of pride, and attitudes $(34,35,36)$ represent the concept of national unity.

\section{Study Results}

9.1 Results Related to the First Question: What Is the Degree of Assimilation of the Higher Basic Stage School Students to the Meaning of the Term Citizenships in Jordan?

To answer this question, the arithmetic means, standard deviations, levels and relative importance have been extracted for the answers of the respondents on the items of the scale related to each concept separately, and Table 2 illustrates this:

Table 2. Arithmetic means, standard deviations, level, total degree and relative importance for the answers of the respondents on the items of the scale related to each concept separately

\begin{tabular}{cclccc}
\hline Level & Number & \multicolumn{1}{c}{ Concept } & $\begin{array}{c}\text { Arithmetic } \\
\text { Mean }\end{array}$ & $\begin{array}{c}\text { Standard } \\
\text { Deviation }\end{array}$ & $\begin{array}{c}\text { Relative } \\
\text { Importance }\end{array}$ \\
\hline 4 & 1 & Belongingness & 2.54 & 0.70 & $82 \%$ \\
3 & 2 & Loyalty & 2.61 & 0.83 & $86.6 \%$ \\
7 & 3 & Rights & 2.73 & 0.92 & $80.3 \%$ \\
8 & 4 & Duties & 2.35 & 1.03 & $78.4 \%$ \\
6 & 5 & Justice & 2.37 & 0.99 & $80.3 \%$ \\
11 & 6 & Cooperation & 2.20 & 0.97 & $73.3 \%$ \\
10 & 7 & Solidarity & 2.24 & 0.92 & $74.5 \%$ \\
9 & 8 & Equity & 2.34 & 1.00 & $78 \%$ \\
5 & 9 & Responsibility & 2.45 & 1.17 & $81.6 \%$ \\
12 & 10 & Participation & 2.01 & 0.96 & $67 \%$ \\
1 & 11 & Pride & 2.81 & 0.99 & $91.6 \%$ \\
2 & 12 & National Unity & 2.77 & 0.83 & $87.7 \%$ \\
\hline & & Total & 2.42 & 0.58 & $81 \%$ \\
\hline
\end{tabular}

Table 2 shows that, the arithmetic mean of the overall performance of the study sample for all concepts is 2.42 , and the standard deviation is 0.58 , and the relative importance is $81 \%$, which is within the positive assimilation level. The arithmetic means ranged between 2.81 for the concept of pride and 2.01 for the concept of participation. And it's clear as well that concept of cooperation, solidarity and responsibility are within the level of neutral, while showing no negative level assimilation, and this shows that students had internalized the nine concepts of good citizenship.

9.2 Results Related to the Second Question: Does the Degree of Assimilation of the Higher Basic Stage School Students to the Meaning of the Term Citizenships in Jordan Vary according to Gender?

To answer this question, the arithmetic means, standard deviations, and (T) value have been extracted for the answers of the respondents on the items of the scale related to each concept upon gender variable, and Table 3 illustrates this: 
Table 3. Arithmetic means, standard deviations and (T) value for the answers of the respondents related to the concepts of good citizenship upon gender variable

\begin{tabular}{|c|c|c|c|c|c|c|}
\hline \multirow{2}{*}{ Concept } & \multicolumn{2}{|c|}{ Male } & \multicolumn{2}{|c|}{ Female } & \multirow{2}{*}{$\begin{array}{c}\mathrm{T} \\
\text { value }\end{array}$} & \multirow{2}{*}{$\begin{array}{c}\text { Level of } \\
\text { Significances }\end{array}$} \\
\hline & $\mathrm{AM}$ & SD & $\mathrm{AM}$ & SD & & \\
\hline Belongingness & 2.38 & 0.62 & 2.51 & 0.56 & -4.83 & $0.000^{*}$ \\
\hline Loyalty & 2.13 & 0.53 & 2.28 & 0.43 & -6.86 & $0.000^{*}$ \\
\hline Rights & 2.46 & 0.64 & 2.75 & 0.52 & -11.40 & $0.000^{*}$ \\
\hline Duties & 1.29 & 0.62 & 2.21 & 0.52 & -11.06 & $0.000^{*}$ \\
\hline Justice & 2.32 & 0.55 & 2.53 & 0.41 & -9.43 & $0.000^{*}$ \\
\hline Cooperation & 2.25 & 0.57 & 2.41 & 0.50 & -6.34 & $0.000^{*}$ \\
\hline Solidarity & 2.03 & 0.65 & 2.43 & 0.54 & -14.49 & $0.000^{*}$ \\
\hline Equity & 2.18 & 0.67 & 2.49 & 0.60 & -10.56 & $0.000^{*}$ \\
\hline Responsibility & 2.12 & 0.67 & 1.97 & 0.72 & 4.79 & $0.000^{*}$ \\
\hline Participation & 2.21 & 0.54 & 2.18 & 0.51 & 1.44 & 0.150 \\
\hline Pride & 2.37 & 0.55 & 2.48 & 0.50 & -4.58 & $0.000^{*}$ \\
\hline National Unity & 2.37 & 0.51 & 2.33 & 0.50 & 1.83 & 0.067 \\
\hline Total & 2.23 & 0.54 & 2.38 & 0.49 & 1.67 & $0.000^{*}$ \\
\hline
\end{tabular}

*Statistically significant at $(\alpha \leq 0.05)$.

Table 3 shows that there are statistically significant differences at $(\alpha \leq 0.05)$ related to gender variable, and by comparing the arithmetic means the results in Table (3) show that the differences were for the favor of females in the concepts: Belongingness, Loyalty, Rights, Duties, Justice, Cooperation, Solidarity, Pride and Equity, but the concept of Responsibility was for the favor of males, while there are no statistically significant differences for the concepts of Participation and National Unity.

9.3 Results Related to the Third Question: Does the Degree of Assimilation of the Higher Basic Stage School Students to the Meaning of the Term Citizenships in Jordan Vary according to Place of Residence?

To answer this question, the arithmetic means, standard deviations, and $(\mathrm{T})$ value have been extracted for the answers of the respondents on the items of the scale related to each concept upon gender variable, and Table 4 illustrates this: 
Table 4. Arithmetic means, standard deviations and (T) value for the answers of the respondents related to the concepts of good citizenship upon the place of residence variable

\begin{tabular}{|c|c|c|c|c|c|c|}
\hline \multirow{2}{*}{ Concept } & \multicolumn{2}{|c|}{ City } & \multicolumn{2}{|c|}{ Village } & \multirow{2}{*}{$\begin{array}{c}\mathrm{T} \\
\text { value }\end{array}$} & \multirow{2}{*}{$\begin{array}{c}\text { Level of } \\
\text { Significances }\end{array}$} \\
\hline & $\mathrm{AM}$ & SD & $\mathrm{AM}$ & $\mathrm{SD}$ & & \\
\hline Belongingness & 2.22 & 0.51 & 2.49 & 0.48 & 2.105 & $0.035^{*}$ \\
\hline Loyalty & 2.16 & 0.65 & 2.28 & 0.62 & -2.679 & $0.007 *$ \\
\hline Rights & 2.47 & 0.49 & 2.35 & 0.52 & -3.572 & $0.000^{*}$ \\
\hline Duties & 2.40 & 0.38 & 2.29 & 0.40 & -1.917 & $0.005^{*}$ \\
\hline Justice & 2.45 & 0.60 & 2.48 & 0.59 & -0.828 & 0.408 \\
\hline Cooperation & 2.59 & 0.57 & 2.66 & 0.53 & -2.294 & $0.022 *$ \\
\hline Solidarity & 2.24 & 0.43 & 2.42 & 0.40 & -4.871 & $0.0001^{*}$ \\
\hline Equity & 2.33 & 0.51 & 2.28 & 0.39 & -1.326 & 0.185 \\
\hline Responsibility & 2.56 & 0.56 & 2.32 & 0.65 & -1.923 & 0.055 \\
\hline Participation & 1.96 & 0.61 & 2.20 & 0.56 & -6.044 & $0.0001 *$ \\
\hline Pride & 2.22 & 0.53 & 2.21 & 0.53 & -14.49 & $0.000^{*}$ \\
\hline National Unity & 2.42 & 0.52 & 2.45 & 0.48 & -10.56 & $0.000^{*}$ \\
\hline Total & 2.34 & 0.52 & 2.37 & 0.52 & -5.346 & $0.001 *$ \\
\hline
\end{tabular}

*Statistically significant at $(\alpha \leq 0.05)$.

Table 4 shows that there are statistically significant differences at $(\alpha \leq 0.05)$ related to the place of residence variable, and by comparing the arithmetic means the results in Table 4 show that the differences were for the favor of village residents in the concepts: Belongingness, Loyalty, Participation, Cooperation, Solidarity and National Unity, but the concepts of Rights, Duties and Pride was for the favor of city residents, while there are no statistically significant differences for the concepts of Justice, Responsibility and Equity.

\section{Discussion}

Results of the study were discussed according to the order in which they presented previously and as follows:

\subsection{Results Discussions Related to the First Question}

Results in Table 2 show that the student's degree of assimilation to the meaning of the term citizenships at the higher basic stage in the schools in Jordan came within the level of positive assimilation indicating the strength of students understanding of these concepts of good citizenship, and that the students of higher basic stage interact with these national concepts and practices in all areas of their daily lives, which express their attachment to the values, customs, traditions and cultural heritage, as they are the "Knights of change" according to the invitation of King Abdullah. With regard to the concepts of cooperation, solidarity and responsibility the students assimilation of these concepts came within the neutral level, and this may be due to the weakness of the experiences of the students in these areas, and as a result of not giving them the opportunity to participate, or the lack of opportunities that suit their age and their level of study.

\subsection{Results Discussions Related to the Second Question}

Table 3 shows that there are statistically significant differences at $(\alpha \leq 0.05)$ due to gender variable, in favor of females, and this means that females are more represented to the concepts of good citizenship than males, this result is due to the change in the nature and practices of education in various institutions to the changing social role of women in the Jordanian society in terms of equality, independence and equal opportunities, which helped in forming a clear picture of the whole concept of good citizenship, where women gained the respect and appreciation of the community in various denominations, and probably due to the opened doors of education for both males and females and the disappearance of the perception of the human being, male or female, they both continued to receive the same treatment. When comparing the arithmetic means in Table 3, it shows that the differences were in the favor of females for the concepts of: Belongingness, loyalty, rights, duties, justice, cooperation, solidarity and equality, while the concepts of responsibility and pride were in favor of males, and this confirms the nature of female and that in the Eastern societies males bear more responsibilities than females. 


\subsection{Results Discussions Related to the Third Question}

Results in Table 4 indicate that there is a statistically significant difference at the level of significance $(\alpha \leq 0.05)$ attributed to the place of residence of the student, and when comparing the arithmetic means, the results show that the differences were in favor of students living in the countryside for the degree representing the concepts of good citizenship, and these concepts are: Belongingness, loyalty, cooperation, solidarity, participation and national unity, because students are affected by the convictions of their families and their positive attitudes because the place of residence gives them a sense of overall satisfaction, stability and a sense of belongingness and commitment more than the city residence. Regarding the concepts of rights, duties, and pride the differences were in favor of the city residences, as a reason of the city's diverse environment, offering many life activities that enable more participating.

The results of this study goes in line with the results of Al-Saeed's (2006) study, referring to the differences in the degree of representing the students to a set of social values attributed to the place of residence for the favor of those who live in cities.

\section{Recommendations}

(1) Enriching curricula with concepts, practices and principles of good citizenship.

(2) Focus on moral education, so as to lead to the social commitment of the common humanity values.

(3) Adoption of the spiral curriculum in the educational process in relation to the concepts of good citizenship planted in the hearts of students at various stages.

(4) Assigning a weekly class session for the week of community service (volunteer work, cleaning the neighborhood ... etc).

(5) Conducting more studies on other concepts related to citizenship as a complementary of this research by linking it with other variables.

\section{References}

Al-Qahtani, A. B. S. A.-A. (2010). The values of citizenship in young people and their contribution in strengthening the Preventive Security (Unpublished Ph.D. thesis, Naif University, Riyadh, Saudi Arabia).

Al-Saeed, B. M. (2006). Degree of representing the higher basic stage students of social values in the schools of Amman and the factors influencing them (Unpublished Ph.D. thesis, University of Jordan, Amman, Jordan).

Al-Subaihi, A. N. (2005). Citizenship as envisioned by high school students in Saudi Arabia. Thirteenth meeting of the educational leaders, Directorate General of Education in Al-Baha, Saudi Arabia.

England, T. (2000). Rethinking Democracy and Education: Towards an education of deliberative citizens. Journal of Curriculum Studies, 32(1), 305-313.

Hassan, M. (2002). Education and Culture of Peace. Al tarbiya Journal, 140(31), 62-77.

Jarrar, A., \& Althubetat, Q. (2013). Peace Concepts in Civic Education Curriculum: A Jordanian. Journal of Education and Practice, 4(6).

Kerr, D. (2003). Citizenship an Education Age 14. Summary of the International Finding and Preliminary Results for England.

Nasser, I. (2003). Citizenship. Al-Raead scientific library, Amman.

Nasser, I. (2004). Foundations of Education. Al-Raead scientific library, Amman.

Tarabiya. (2002). Political concepts contained in the high school curriculum in Jordan, and the extent of awareness of students in the first academic year of these concepts. Amman, Jordan: Dar Wael publications.

\section{Copyrights}

Copyright for this article is retained by the author(s), with first publication rights granted to the journal.

This is an open-access article distributed under the terms and conditions of the Creative Commons Attribution license (http://creativecommons.org/licenses/by/3.0/). 